\title{
Legal Aid Institutions as a State Solution for the Poor in Getting Legal Protection
}

\author{
Auliya Rochman \\ Lawyer and Solicitor, Auliya Rochman Law Office, Indonesia \\ Corresponding Author: A. Rochman, email: rochman18.sh@gmail.com
}

\begin{abstract}
This study examines how the rules of the Legal Aid Institute in providing legal protection to the poor in Indonesia. As well as how the implementation of legal aid institutions in Indonesia in providing legal protection to the poor to examine the problem, the research method used is normative legal research methods with the statute approach, and the conceptual approach. The legal material collection technique used in this research is literature study. Research results confirm that poverty is one of the biggest problems in upholding human rights in obtaining legal assistance. The human rights approach is one of the basic principles of the government in serving people who are unable to overcome or provide legal protection in facing legal problems that are being faced either criminal, civil or state administration, so that the rights of the poor are not lost. Implementation of Providing Legal Aid is a law of social justice, where these values include respecting the dignity and rights of individuals before the law, addressing the imbalance of power and legal injustice between the rich and the poor.
\end{abstract}

Keywords: Legal Aid Institute; Legal Services; Poor People; Legal Protection; Human Rights

\section{How to cite:}

Rochman, A. (2020). Legal Aid Institutions as a State Solution for the Poor in Getting Legal Protection. Indonesian Journal of Advocacy and Legal Services, 2(2), 211-222 https://doi.org/10.15294/ijals.v2i2.38147

\section{A. Introduction}

Indonesia is a country that guarantees the constitutional rights of every society to get recognition, guarantee, protection, and legal certainty that is 


\section{A. Rochman}

just and equal treatment before the law. According to article 1 of Law Number 16 of 2011 concerning Legal Aid, it explains that legal aid is legal services provided by legal aid providers free of charge to legal aid recipients and in the Constitution Article 27 Paragraph (1) which reads, "Citizens have an equal position in the law and the government is obliged to adhere to the law and government without exception." With the regulation of this regulation, not many people understand what legal aid is. Many people just give up in facing the legal problems they experience. ${ }^{1}$ The regulations that have regulated legal aid cannot be separated from its function as a vital means of access for people who do not understand the law in order to obtain justice, especially for the poor who are caught in cases. ${ }^{2}$ Many poor people do not understand about the free legal aid that is facilitated by the state through the Legal Aid Institute. ${ }^{3}$

Legal aid institutions have an important role in providing enlightenment of the public in the justice system in Indonesia. Legal aid institutions are expected to provide legal education to people who do not understand legal aid and the judicial system in Indonesia. ${ }^{4}$ Whereas legal assistance is defined as legal advice, assistance and / or with little or no cost to the person designated as entitled to it, in other words legal assistance is provided by legal aid agencies to the public who need justice in Litigation law at cost or free-only. Legal Aid also includes services provided by Advocates and paralegals in the non-litigation field. As for the obstacles of the Legal Aid Institute in providing legal assistance is Access to people who do not yet know the function of the Legal Aid Institute. ${ }^{5}$

Through legal and development practices aimed at increasing access to justice and supporting legal aid, legal awareness programs, and court reform aimed at better access, based on the description above, the problem in this study is to explain some important issues concerning: (1) what are the legal

1 Ridwan Arifin, "Legal Services and Advocacy in the Industrial Revolution 4.0: Challenges and Problems in Indonesia." Indonesian Journal of Advocacy and Legal Services Vol. 1 No. 2, 2020, pp. 159-162.

2 Muten Nuna, Dince Aisa Kodai, \& Roy Marthen Moonti, "Code of Ethics and The Role of Advocates in Providing Legal Aid to The Poor", Indonesian Journal of Advocacy and Legal Services Vol. 1 No. 2, 2020, pp.259-274.

3 Akhdiari Harpa, "Analisis Yuridis Pemberian Bantuan Hukum Bagi Masyarkat Miskin Dalam Mewujudkan Akses Keadilan Terhadap Masyarakat Miskin”, Tadulako Master Law Journal Vol. 3 No. 2, 2019, pp.113-124.

4 Mustika Prabaningrum Kusumawati, "Peranan dan Kedudukan Lembaga Bantuan Hukum sebagai Access to Justice bagi Orang Miskin”, Arena Hukum Vol. 9 No. 2, 2016, pp. 190-206.

5 Angga \& Ridwan Arifin, "Penerapan Bantuan Hukum Bagi Masyarakat Kurang Mampu di Indonesia", DIVERSI: Jurnal Hukum Vol. 4 No. 2, 2019, pp. 218-236; Eka NAM Sihombing, "Eksistensi Paralegal dalam Pemberian Bantuan Hukum bagi Masyarakat Miskin”, Jurnal Ilmiah Penegakan Hukum Vol. 6 No.1, 2019, pp. 70-77. 
rules of the Legal Aid Institute in providing legal protection to the poor in Indonesia?, and (2) how is the implementation of the Legal Aid Institute in Indonesia in providing legal protection to the poor?

\section{B. Method}

This paper focuses on normative research, because in this legal research, law is conceptualized as what is written in legislation (law in books) or the law is conceived as rules or norms which constitute a standard of human behavior that is considered appropriate. ${ }^{6}$

The research uses a statutory approach and a conceptual approach. The legislative approach referred to by the authors in this study is to study the laws concerning the Legal Aid Institution. While the conceptual approach moves from the views and doctrines in the science of law, researchers will find ideas that give birth to legal understandings, legal concepts, and legal principles that are relevant to the issue at hand. Understanding of these views and doctrines is the basis for researchers to build a legal argument in solving the issues being examined.7

\section{Results and Discussions}

\section{Provision for Legal Aid Institutions in Providing Legal Protection to the Poor in Indonesia}

The many problems faced by people in contact with the law one of which, can be a very big problem especially the poor who have no understanding of the rule of law, even though Article 4 of Law Number 16 of 2011 concerning Legal Aid, has made it clear that legal aid is given to legal aid recipients who face legal problems. Areas of legal assistance that can be provided include civil, criminal, and state administrative cases. Legal aid activities can be in the form of litigation and non-litigation.

The provision of legal assistance is carried out in the context of exercising power, accompanying, representing, defending, and / or carrying out other legal actions for the legal benefit of the Legal Aid Recipient. Based on the description above, it is very clear that the Law on Legal Aid has limited the qualifications of those who receive legal assistance, namely the poor or

6 Amirudin \& Zainal Asikin, Pengantar Metode Penelitian Hukum, Raja Grafindo Persada, Jakarta, 2004, pp. 34-35.

7 Peter Mahmud Marzuki, Penelitian Hukum, Prenadamedia Group, Jakarta, 2014, p.136. See also Amanda Perry-Kessaris, "Legal Design for Practice, Activism, Policy, and Research", Journal of Law and Society Vol. 46 No. 2, 2019, pp. 185-210. 
the poor. With the explanation in this article the people who are unable are entitled to legal assistance and legal protection both in litigation and nonlitigation.

In Article 5 of Law Number 16 of 2011 concerning Legal Aid also reinforces the explanation of article 4 of Law Number 16 of 2011 concerning Legal Aid which states:

(1) Recipients of Legal Aid as referred to in Article 4 paragraph (1) covers every poor people or groups of people who cannot properly and independently fulfil basic rights.

(2) The basic rights referred to in paragraph (1) include the right to food, clothing, health services, education services, work, and business, and / or housing.

It also emphasized that Legal Aid recipients as referred to in Article 4 paragraph (1) include every person or group of poor people who cannot fulfil their basic rights properly and independently. The basic rights referred to in paragraph (1) include the right to food, clothing, health services, education services, work, and business, and/or housing.

Although it has been explained in article 4 and article 5 of Law Number 16 of 2011 regarding Legal Aid that in practice the justice system may be difficult to understand and direct, such as lack of financial resources, lack of awareness about how to access the justice system, and long distances to reach legal service providers. As a result, legal aid which should be a means for poor people who are affected by law becomes useless in Indonesia in overcoming legal obstacles.

Means that, providers of legal aid services, such as lawyers, paralegals, and law students, thus play an important role by assisting people to obtain their rights and rights, obtain compensation for complaints, and ensure appropriate defence in criminal proceedings. Moreover, Article $28 \mathrm{D}$ Paragraph (1) of the 1945 Constitution states that everyone has the right to recognition, guarantees of protection and fair legal certainty and equal treatment before the law. The International Covenant on Civil and Political Rights which has been ratified by Indonesia by Law Number 12 of 2005 in Article 14 also protects the right of everyone to get the same legal treatment without discrimination. Thus, the right to legal assistance is a constitutional right for the people of this country. ${ }^{8}$

8 Adnan Buyung Nasution, Bantuan Hukum Di Indonesia, Jakarta: LP3ES, 2007, pp.2-5. 
Poverty is one of the biggest problems in upholding human rights in obtaining legal assistance. The human rights approach to development is one of the basis for the government in serving the people who are unable to overcome or provide legal protection in the face of legal problems that are being faced either criminal, civil or state administration, so that the rights of the poor are not lost. In problems in the community, access to legal assistance for poor groups settling disputes over land and families will be able to help the poor and marginalized by giving them information and support to enable them to claim their rights, use their assets, and give them access to services and benefits to which they are entitled under the law.

Whereas in Article 6 paragraph (1) and (2) of Law Number 16 of 2011 concerning Legal Aid, the contents are: "Legal Aid held to help resolve legal problems faced by Legal Aid Recipients". While the Provision of Legal Aid to Legal Aid Recipients is carried out by the Minister and carried out by the Legal Aid Providers under this Law. In this case, advocacy competence is the main key in providing legal assistance, because the defence is not formal but substantial, so it really defends with sincerity and professionalism as the law enforcement process in general. Therefore, that both the legal aid provider and the recipient of legal assistance will both get their rights before the law.

\section{Implementation of Legal Aid Institutions in Indonesia in Providing Legal Protection for the Poor}

Legal empowerment is not about assistance, but about helping and protecting the poor lifting themselves out of poverty and protecting their rights in law. M. Yahya Harahap argues that the notion of legal aid has characteristics in different terms ${ }^{9}$, namely among others:

a. Legal aid, which means providing services in the field of law to someone involved in a case or case, namely:

1) Providers of legal aid services are free of charge

2) Legal service assistance in legal aid is more specifically for the poor in the poorer segments of society

3) Thus, the main motivation in the concept of legal aid is to uphold the law by defending the interests and human rights of the common people who do not have legal illiteracy.

9 Darman Primts, Hukum Acara Pidana dalam Praktek, Jakarta, Penerbit Djambatan, 2002, p. 102. See also Sviatoslav Antoniuk, "Lawyer as a Subject of Providing Legal Assistance to a Client on a Professional, Independent basis", Path of Science Vol. 5 No. 5, 2019, pp. 4001-4015; Dimitrios Giannoulopoulos, "Strasbourg jurisprudence, law reform and comparative law: a tale of the right to custodial legal assistance in five countries", Human Rights Law Review Vol. 16 No. 1, 2016, pp. 103-129. 


\section{A. Rochman}

b. Legal assistance, which contains a broader understanding of legal aid. Because besides containing the meaning and purpose of the service provider legal aid, closer to understanding known as advocates, namely aid providers:

1) Both those who can afford the achievement,

2) As well as, providing assistance to people who are poor for free.

c. Legal service, namely legal servants, in the Indonesian language translated into legal services. In general, most people are more inclined to provide a broader understanding of the concept and meaning of legal service compared to the purpose and objectives of legal aid or known assistance, because in legal service concepts and ideas sometimes the meaning and purpose:

1) Providing assistance to community members whose operations are aimed at eradicating the discriminatory reality of the enforcement and provision of legal aid services between poor people on low incomes and rich people who control sources of funds and positions of power.

2) And with legal services provided to members of the community in need, the truth of the law itself can be realized by law enforcers. By respecting every law justified right for every member of the community without differentiating between the rich and the poor.

3) Besides that, to uphold the law and respect for the rights given by the law to everyone, legal services in their operations are more likely to resolve any dispute by taking the peace method.

The definition of "legal assistance" also includes services provided by lawyers and paralegals in criminal, civil and state administrative matters to individuals who are poor, marginalized, or need special legal protection, to enable them to exercise their rights. This includes providing legal advice, defence, mediation, assistance inside and outside the court. Explained in Article 3 of Law number 16 of 2011 concerning Legal Aid contents:

1) Guarantee and fulfil the right for Legal Aid Recipients to get access to justice

2) Realizing the constitutional rights of all citizens in accordance with the principle of equality in law

3) Guaranteeing certainty that the implementation of Legal Aid is carried out evenly throughout the territory of the Republic of Indonesia; and

4) Realizing an effective, efficient, and able justice accounted for.

In the elucidation of Article 3 of Law number 16 of 2011 concerning Legal Aid, it explains that the government has provided legal aid access to the poor and disadvantaged in the form of Legal Aid Institutions in fulfilling 
their rights in the criminal, civil and administrative fields. And the government has guaranteed equality before the law in dealing with legal issues. So, if the recipient of legal aid in carrying out litigation problems legal aid can be interpreted as providing legal aid services by acting either as a defender of someone who is involved in a criminal case or as a proxy in a civil case, or in a state administration case before a court of law, and or give legal advice outside the court. ${ }^{10}$

Further explained in Article 37 of Law No. 4 of 2004 concerning Judicial Power which states that: "Every person involved in a case has the right to receive assistance law". in other words both the poor and rich in terms of providing legal assistance the government has provided legal assistance, either choosing their own legal counsel or the Government facilitating it by appointing legal aid institutions to assist the recipients of legal aid and reaffirmed in Article 38 of Law No. 4 of 2004 concerning Judicial Power confirms: "The criminal case of a suspect from the moment of arrest and / or detention has the right to contact and ask for advocate's assistance". ${ }^{11}$

Then, in Article 39 of Law No. 4 of 2004 concerning Judicial Power states: "In providing legal assistance as referred to in article 37, where an advocate is obliged to assist the settlement of cases by upholding law and justice". In other words, in Article 39 it is explained that the legal aid provider in this case is the Advocate must provide legal assistance that does not differentiate both from the poor or from the rich and upholds law and justice in order to create clean law. It is discussed in Article 28D Paragraph (1) of the 1945 Constitution, namely that every person has the right to recognition, guarantees, protection, and fair legal certainty and equal treatment before the law.

In Access to Justice for the Poor, Marginalized and Vulnerable People of Uganda, the Legal Aid Service Providers Network (LASPNET), explains This Document is the outcome of a conference of 115 practitioners in 2007, and it is meant to influence among others national governments, legal aid bodies and organizations. It is an advanced document in stating many important principles of access to justice as human rights. The preamble

10 Lasdin Wlas, Cakrawala Advokat Indonesia, Yogyakarta, Liberty, 1989, p. 119. For another perspective, please also see Armada Wibowo, "Analisis Yuridis Normatif Larangan Beriklan Untuk Advokat dalam Kode Etik Advokat Indonesia", Thesis, University of Muhammadiyah Malang, 2019, pp. 37-40.

11 Helmy Yahya Rahma Aji \& Raden Muhammad Arvy Ilyasa, "The Existence of the State's Role in Providing Prodeo Legal Aid to Citizens Who Are Not Able Based on Law Number 16 of 2011", The Indonesian Journal of International Clinical Legal Education Vol. 2 No. 2, 2020, pp. 111-128; Cahya Wulandari, "The Pro Bono Publico Prodeo Legal Aid System Model for the Poor Society in Indonesia”, 1st International Conference on Indonesian Legal Studies (ICILS 2018). Atlantis Press, 2018. 


\section{A. Rochman}

recognises that citizens of many states are denied access to justice and are ignorant about their human and legal rights and procedures. It states that justice for all can only be realized when its rules and operations are understandable and accessible to all, and that the provision of legal aid is a vital in promoting access to justice. The preamble also highlights the benefits of legal aid, including elimination of unnecessary detention, speedy processing of cases, fair and impartial trials and dispute resolution, the reduction of prison populations, the lowering of appeal rates, decreased reliance on a range of social services, the advancement of social and economic rights, and greater social harmony. ${ }^{12}$

The main meaning is the influence of the national government, legal aid agencies and organizations in declaring many important principles of access to justice as human rights. where this procedure states that justice for all can only be realized when the rules are only if the operation is understandable and accessible to all, and that the provision of legal assistance is vital in promoting access to justice. It is also highlighted the benefits of legal aid, including the elimination of unnecessary detention, fast processing of cases, fair and impartial trials as well as dispute resolution and advancement of social and economic rights, and greater social harmony.

Furthermore, The Declaration covers 14 key areas; Recognizing and supporting the right to legal aid in the justice system: Providing legal aid at all stages of the justice process: Sensitizing all government officials: Viewing legal aid as one means of ensuring a justice system that is accessible and available to all: Cooperating with other stakeholders and the public: Recognizing the right to redress for violations of human rights: Recognizing the role of non-formal means of conflict resolution: Diversifying legal aid delivery systems: Diversifying legal aid service providers: Encouraging pro bono provision of legal aid by lawyers : Guaranteeing sustainability of legal aid: Promoting legal literacy through legal education and advocacy: Ensuring access to justice in programs of assistance to systems in developing and

12 LASPNET, "Access to Justice for the Poor, Marginalised and Vulnerable People of Uganda", Research Report, Legal Aid Service Providers Network (LASPNET), KampalaUganda, 2015, p. 27. The report also emphasized that, it should be noted that even though the terms are used together they are not interchangeable as stated clearly in the definitions above. There are numerous groups and categories who can be considered as poor, vulnerable, and marginalised. They include people with neglected and often misunderstood diseases (including the mentally ill, nodding disease victims, and other such diseases in Uganda). They include Persons with Disabilities, the Elderly, lonely and isolated, Children, especially those who have disabilities, are refugees, or fall into other categories of vulnerable groups. Children with Parents in Prison, children who head households and the homeless should not be left out. 
transitional countries and: Guaranteeing a secure environment for the provision of legal aid. ${ }^{13}$

The main meaning of this declaration includes Recognizing and supporting the right to legal assistance in Indonesia and its justice system, Providing legal assistance at all stages of the judicial process, Sensitization of all government Officials in Seeing legal aid as a way to ensure a justice system that is accessible and available to all aspects, Cooperating with other stakeholders and the public, Recognizing the right to compensation for violations of human rights, Recognizing the role of non-formal conflict resolution means, Diversifying legal aid delivery systems, Diversifying legal aid service providers, Encouraging pro-legal assistance bono by lawyers, Ensuring the sustainability of legal aid, Promoting legal literacy through legal education and advocacy, Ensure access to justice in legal aid programs for the justice system in developing and transition countries, and Ensure a safe environment for the provision of legal assistance.

Providing Legal Aid is a law of social justice, where these values include respecting the dignity and rights of individuals before the law, addressing the imbalance of power and legal injustice between the rich and the poor.

\section{Conclusion}

This paper concludes that highlighting the Legal Aid Institute in providing legal protection to the poor in Indonesia, Poverty is one of the biggest

13 Furthermore, it is highlighted that the government of Uganda is making some effort to address the lack of access to justice through the State Briefs scheme for persons charged with capital offences, the Pro bono scheme run by Uganda Law Soceity, allowing Students to offer legal aid and the establishment of the Justice Centres. The efforts of the various non-governmental Legal Aid Service Providers (LASPs) also help substantially to fill the gap. However, access to justice remains limited for various reasons. For example, most of the JLOS services remain in the urban areas and central region. This creates a physical barrier that may result in victims or users not attempting to close the distance gap hence choosing to relinquish their rights. The Justice Centres that provide critical legal aid are found in only four satellite locations. Only $18.2 \%$ of the people in rural areas are able to access a Magistrate Court within a distance of less than $5 \mathrm{~km}$ compared to an overwhelming $56 \%$ in urban areas. There are challenges of raising resources for transportation to the relevant institutions. Ibid. For comparison on another sector, please see also Kiwanuka, S. N., Ekirapa, E. K., Peterson, S., Okui, O., Rahman, M. H., Peters, D., \& Pariyo, G. W., Access to and utilisation of health services for the poor in Uganda: a systematic review of available evidence. Transactions of the Royal Society of Tropical Medicine and Hygiene, Vol. 102 No. 11, 2008, pp. 1067-1074; C. Nanjala, (Determinants of effective legal Aid service delivery in Kenya. International Journal of Social Sciences and Enterpreneurship, Vol. 1 No. 5, 2013, pp. 271-288; Hennie Van As, "Taking legal aid to the people: unleashing local potential in South Africa." Obiter Vol. 26 No. 2, 2005, pp. 187-206. 


\section{A. Rochman}

problems in upholding human rights in obtaining legal assistance. The human rights approach to development is one of the foundations of government in serving people who are unable to overcome or provide legal protection in the face of legal problems that are being faced either criminal, civil or state administration, so that the rights of the poor are not lost. The implementation of the Legal Aid Institute in Indonesia in providing legal protection to the poor is a specific challenge and priority area in various aspects of legal aid delivery. Recognize and support the right to legal assistance in Indonesia and the justice system, provide legal assistance at all stages of the judicial process, guarantee legal assistance sustainability, provide legal literacy through legal education and advocacy, ensure access to justice in legal aid programs for the justice system and Ensure a safe environment for the provision of legal assistance.

\section{E. Acknowledgment}

Author would like to thank to all Team from Auliya Rochman Law Office in Sragen, Indonesia. Also, to some legal practitoners and laywers affiliated to that office.

\section{F. Declaration of Conflict of Interest}

The author states that there is no potential conflict of interest in the research, authorship, and/or publication of this article.

\section{G. Funding}

The author does not obtain financial support from any party for research, authorship, and/or publication of this article.

\section{H. References}

Aji, H. Y. R., \& Ilyasa, R. M. A. (2020). The Existence of the State's Role in Providing Prodeo Legal Aid to Citizens Who Are Not Able Based on Law Number 16 of 2011. The Indonesian Journal of International Clinical Legal Education, 2(2), 111-128.

Amirudin, A., \& Asikin, Z. (2004). Pengantar Metode Penelitian Hukum. Jakarta: Raja Grafindo Persada. 
Angga, A., \& Arifin, R. (2019). Penerapan Bantuan Hukum Bagi Masyarakat Kurang Mampu di Indonesia. DIVERSI: Jurnal Hukum, 4(2), 218236.

Antoniuk, S. (2019). Lawyer as a Subject of Providing Legal Assistance to a Client on a Professional, Independent basis. Path of Science, 5(5), 4001-4015.

Arifin, R. (2020). Legal Services and Advocacy in the Industrial Revolution 4.0: Challenges and Problems in Indonesia. Indonesian Journal of Advocacy and Legal Services, 1(2), 159-162.

Giannoulopoulos, D. (2016). Strasbourg jurisprudence, law reform and comparative law: a tale of the right to custodial legal assistance in five countries. Human Rights Law Review, 16(1), 103-129.

Harpa, A. (2019). Analisis Yuridis Pemberian Bantuan Hukum Bagi Masyarkat Miskin dalam Mewujudkan Akses Keadilan Terhadap Masyarakat Miskin. Tadulako Master Law Journal, 3(2), 113-124.

Kiwanuka, S. N., Ekirapa, E. K., Peterson, S., Okui, O., Rahman, M. H., Peters, D., \& Pariyo, G. W. (2008). Access to and utilisation of health services for the poor in Uganda: a systematic review of available evidence. Transactions of the Royal Society of Tropical Medicine and Hygiene, 102(11), 1067-1074.

Kusumawati, M. P. (2016). Peranan dan Kedudukan Lembaga Bantuan Hukum sebagai Access to Justice bagi Orang Miskin. Arena Hukum, 9(2), 190-206.

LASPNET. (2015). "Access to Justice for the Poor, Marginalised and Vulnerable People of Uganda", Research Report, Legal Aid Service Providers Network (LASPNET), Kampala-Uganda. Retrieved from https://namati.org/wp-content/uploads/2015/12/Access-to-Justice-forthe-Poor-Marginalised-and-Vulnerable-People-of-Uganda.pdf

Marzuki, P. M. (2014). Penelitian Hukum. Jakarta: Prenadamedia Group.

Nanjala, C. (2013). Determinants of effective legal Aid service delivery in Kenya. International Journal of Social Sciences and Enterpreneurship, 1(5), 271-288.

Nasution, A. B. (2007). Bantuan Hukum Di Indonesia. Jakarta: LP3ES.

Nuna, M., Kodai, D. A., \& Moonti, R. M. (2020). Code of Ethics and the Role of Advocates in Providing Legal Aid to the Poor. Indonesian Journal of Advocacy and Legal Services, 1(2), 259-274.

Perry-Kessaris, A. (2019). Legal Design for Practice, Activism, Policy, and Research. Journal of Law and Society, 46(2), 185-210.

Primts, D. (2002). Hukum Acara Pidana dalam Praktek. Jakarta: Penerbit Djambatan. 


\section{A. Rochman}

Sihombing, E. N. (2019). Eksistensi Paralegal dalam Pemberian Bantuan Hukum bagi Masyarakat Miskin. Jurnal Ilmiah Penegakan Hukum, 6(1), 70-77.

Van As, H. (2005). Taking legal aid to the people: unleashing local potential in South Africa. Obiter, 26(2), 187-206.

Wibowo, A. (2019). "Analisis Yuridis Normatif Larangan Beriklan Untuk Advokat dalam Kode Etik Advokat Indonesia", Thesis, University of Muhammadiyah Malang.

Wulandari, C. (2018, July). "The Pro Bono Publico Prodeo Legal Aid System Model for the Poor Society in Indonesia". In 1st International Conference on Indonesian Legal Studies (ICILS 2018). Atlantis Press.

Wlas, W. (1989). Cakrawala Advokat Indonesia. Yogyakarta: Liberty. 